\title{
Saccharification of Brown Macroalgae Using an Arsenal of Recombinant Alginate Lyases: Potential Application in the Biorefinery Process ${ }^{\mathbb{S}}$
}

\author{
Javier A. Gimpel ${ }^{1}$, María Cristina Ravanall ${ }^{1,2}$, Oriana Salazar ${ }^{1}$, and María Elena Lienqueo ${ }^{1 *}$ \\ ${ }^{1}$ Centre for Biotechnology and Bioengineering CEBIB, Department of Chemical Engineering, Biotechnology and Materials, Universidad de \\ Chile, 851 Beauchef, Santiago, Chile \\ ${ }^{2}$ Instituto de Ciencia y Tecnología de los Alimentos (ICYTAL), Facultad de Ciencias Agrarias, Universidad Austral de Chile, Avda. Julio \\ Sarrazín s/n, Isla Teja, Valdivia, Chile
}

\author{
Received: May 23, 2018 \\ Revised: August 19, 2018 \\ Accepted: August 20, 2018 \\ First published online \\ August 24, 2018 \\ *Corresponding author \\ Phone: +56-29784709; \\ Fax: +56-226972672; \\ E-mail: mlienque@ing.uchile.cl
}

S upplementary data for this paper are available on-line only at http://jmb.or.kr.

pISSN 1017-7825, eISSN 1738-8872

Copyright@ 2018 by

The Korean Society for Microbiology and Biotechnology

\begin{abstract}
Alginate lyases (endo and exo-lyases) are required for the degradation of alginate into its constituting monomers. Efficient bioethanol production and extraction of bioactives from brown algae requires intensive use of these enzymes. Nonetheless, there are few commercial alginate lyase preparations, and their costs make them unsuitable for large scale experiments. A recombinant expression protocol has been developed in this study for producing seven endo-lyases and three exo-lyases as soluble and highly active preparations. Saccharification of alginate using 21 different endo/exo-lyase combinations shows that there is complementary enzymatic activity between some of the endo/exo pairs. This is probably due to favorable matching of their substrate biases for the different glycosidic bonds in the alginate molecule. Therefore, selection of enzymes for the best saccharification results for a given biomass should be based on screens comprising both types of lyases. Additionally, different incubation temperatures, enzyme load ratios, and enzyme loading strategies were assessed using the best four enzyme combinations for treating Macrocystis pyrifera biomass. It was shown that $30^{\circ} \mathrm{C}$ with a 1:3 endo/exo loading ratio was suitable for all four combinations. Moreover, simultaneous loading of endo-and exo-lyases at the beginning of the reaction allowed maximum alginate saccharification in half the time than when the exo-lyases were added sequentially.
\end{abstract}

Keywords: Endo-alginate lyase, exo-alginate lyase, brown macroalgae biorefinery, brown macroalgae saccharification, brown macroalgae extraction

\section{Introduction}

Alginate is an anionic polysaccharide that is widely used as a gelling or thickener agent in food and beverages, while also having applications in the paper, biomaterials, and pharmaceutical industries [1]. Brown algae (Phaeophyceae) are composed of $\sim 40 \%$ DW alginate, which acts as their main structural cell wall component [2]. Pseudomonas and Azotobacter bacteria can also synthesize alginate for cell adhesion and protection, respectively [3]. All sources of alginate are composed of uronic acid monomers: $\alpha-L-$ guluronate $(\mathrm{G})$ and its C5 epimer $\beta$-D-mannuronate $(\mathrm{M})$, arranged as homopolymeric or heteropolymeric blocks.
The proportion of these blocks varies between alginates from different organisms, while also depending on several environmental factors [4].

Alginate lyases (E.C. 4.2.2.3 and E.C. 4.2.2.11) can cleave the glycosidic bond between alginate monomers by betaelimination. There are two types of alginate lyases, endocleaving alginate lyases, which produce oligoalginates, and exo-cleaving alginate lyases ("oligoalginate lyases"), which release uronic acid monomers. Both types are present in a variety of organisms including algae, mollusks, fungi, bacteria, and viruses. Their functions are related to the synthesis of alginate cell walls or the degradation of alginate as a carbon and energy source [5]. Alginate lyases 
have been assigned by the Carbohydrate-Active Enzymes Database (CAZy) to families 5, 6, 7, 14, 15, 17, and 187 of polysaccharide lyases (PL) based on hydrophobic cluster analysis (http://www.cazy.org/Polysaccharide-Lyases.html), or they can also be classified by their substrate preference for G-G, M-M, or G-M bonds [2].

Alginate lyases have various applications. Oligoalginates produced with these enzymes can act as growth promoting and/or activating factors for probiotic bacteria [6], plants [7-10], endothelial cells [11], and immune cells [12-14]. Oligoalginates can also be used to disrupt pathogenic biofilms [15-17], and inhibit colonization of enteropathogenic bacteria [18]. Alginate lyases are also part of medical treatments for disrupting Pseudomonas aeruginosa alginatebased biofilms and increasing antibiotic efficacy [19-21]. Additionally, alginate lyases are important tools in laboratories for producing brown algae protoplasts for biochemical and genetic transformation studies. In the past years, uronic acids from brown algae produced by endo and exo alginate lyases have become an attractive and sustainable source of fermentable sugars which could be turned into bioethanol, biogas, or some other commodities provided the appropriate metabolic pathways are present [22-30]. On the other hand, the degradation of alginate has been shown to be favorable for the extraction of mannitol and cellulose from algal biomass for using them as alternative sugar sources [31-36]. Alginate lyases have also been proposed for "enzyme-assisted extractions" of highvalue bioactives from brown macroalgae such as carotenoids, fluorescent pigments, fucoidan, and phlorotannins [37-40].

Despite the multiple applications of alginate lyases there are few reports on the production, optimization and utilization of recombinant alginate lyases. Previous publications have dealt with three or fewer recombinant targets, and usually testing either exo or endo lyases, but not both. One of the more complete publications has tested a single exo and a single endo lyase, concluding that it was better to use these enzymes sequentially [24]. Recombinant endo-type enzymes can only be obtained from three commercial sources that report little about enzyme activity in their datasheets (Sigma, Megazyme, and Nippon Gene), while several other companies offer products with no technical specifications. NZYtech offers two recombinant exo-alginate lyases but their use has not been reported in the scientific literature yet. Furthermore, the NZYtechPaAlg7A exo-lyase has been previously characterized as an endolyase [41]. Given the high cost and low quantities offered for the commercial enzymes, it is unviable to include them in the design of pilot or industrial scale processes comprising alginate degradation. Nonetheless, few studies have been dedicated to develop the recombinant production of alginate lyases, and most work has focused on the analytical-scale purification of a single enzyme and its characterization [42-47].

Unfortunately, alginate lyases are regarded as "specialty" enzymes; therefore the mainstream biotechnology research community has neglected them as targets for production, instead favoring plant-biomass-degrading enzymes. It remains then a responsibility for the brown macroalgae research community to develop alginate lyases as an everyday low-cost tool for biorefinery and biochemical research. The first aim of this work is to establish such an approximation by using widespread cultivation and genetic tools for improving expression of endo-alginate lyases in E. coli. We then expand these results for the production of exo-alginate lyases. Past efforts for the saccharification of alginate into its monomers have relied on the use of a single pair of an endo and exo lyase, without testing combinations of different enzyme targets. Our expression platform has allowed us to produce and test 7 endo and 3 exo- lyases as 21 combinations for the saccharification of alginate in order to confirm if the selection of enzyme couples could be adjusted for enhancing product yield. Four enzyme pairs were then further tested with Macrocystis pyrifera biomass to analyze their differential response to temperature, enzyme load, and the order of addition of endo/exo lyases in the saccharification reaction.

\section{Materials and Methods}

\section{Strains and Growth Conditions}

The following E. coli strains were used in this work: DH10B for cloning procedures, BL21 (DE3), BL21 (DE3) pLysS, BL21 (DE3) Rosetta2, and BL21 (DE3) pLysS Rosetta2 were employed as hosts for optimizing recombinant alginate lyase expression (see Supplementary Information). Cloning work was performed using LB medium supplemented with $100 \mu \mathrm{g} / \mathrm{ml}$ ampicillin and/or $34 \mu \mathrm{g} / \mathrm{ml}$ chloramphenicol, $37^{\circ} \mathrm{C}$ growth temperature, and $200 \mathrm{rpm}$ orbital shaking. All transformations were done with chemically competent cells [48]. See below for expression experiments growth condition. Cloning work was performed using LB medium supplemented with $100 \mu \mathrm{g} / \mathrm{ml}$ ampicillin and/or $34 \mu \mathrm{g} / \mathrm{ml}$ chloramphenicol, $37^{\circ} \mathrm{C}$ growth temperature, and $200 \mathrm{rpm}$ orbital shaking. All transformations were done with chemically competent cells [48]. See below for expression experiments growth conditions.

\section{DNA Constructs}

All 18 alginate lyase coding sequences used in this work are presented in Table 1 . The sequences for alyA-D2, alyB, alyD, alySJ02, OalA, OalB, and OalC were amplified from the E. coli strain 
Table 1. Alginate lyase proteins expressed in this study.

\begin{tabular}{|c|c|c|c|c|c|}
\hline Name & Species & Family & Expressed amino acids & NCBI Protein & Reference \\
\hline \multicolumn{6}{|l|}{ Edo-lyase } \\
\hline AlyA-D2 & Vibrio splendidus 12B01 & PL7 & $376-580(205)$ & EAP94921.1 & {$[42]$} \\
\hline AlyB & Vibrio splendidus 12B01 & PL7 & $18-522(505)$ & EAP94922.1 & [42] \\
\hline AlyD & Vibrio splendidus 12B01 & PL7 & $22-345$ (324) & EAP94925.1 & {$[42]$} \\
\hline Aly-SJ02 & Pseudoalteromonassp. SM0524 & PL18 & $175-400(226)$ & 618885355 & [43] \\
\hline AlyPEEC & Pseudoalteromonas elyakovii & PL18 & $166-398(233)$ & 4322372 & [44] \\
\hline AlgmsP & Microbulbifer sp. 6532A & PL7 & 80-358 (279) & 319993261 & {$[46]$} \\
\hline AlyL1 & Agarivorans sp. L11 & PL7 & 24-349 (326) & AIY68670.1 & [43] \\
\hline A1-II & Sphingomonassp. A1 & PL7 & 414-641 (228) & ВАВ03312.1 & [47] \\
\hline A1-II' & Sphingomonas sp. A1 & PL7 & $81-308$ (228) & BAD16656.1 & [45] \\
\hline \multicolumn{6}{|l|}{ Exo-lyase } \\
\hline $\mathrm{Cly}^{*}$ & Cellulophagalytica & PL7 & $12-355(344)$ & WP_038507284.1 & This work \\
\hline $\mathrm{ScbB}^{*}$ & SCB49 unidentified bacterium & PL7 & $17-339$ (323) & EDM45391.1 & This work \\
\hline Atu3025 & Agrobacteriumtumefaciens C58 & PL15 & $1-776$ & NP_357573.1 & {$[62]$} \\
\hline OalA & Vibrio splendidus 12B01 & PL15 & $1-692$ & ЕАР93067.1 & {$[61]$} \\
\hline OalB & Vibrio splendidus $12 B 01$ & PL17 & $1-735$ & ЕАР93062.1 & {$[61]$} \\
\hline OalC & Vibrio splendidus 12B01 & PL17 & $1-717$ & ЕАР93063.1 & {$[61]$} \\
\hline Cat $^{*}$ & Croceibacteratlanticus & PL7 & $17-348(332)$ & WP_013188042.1 & This work \\
\hline Lpe $^{*}$ & Lewinellapersica & PL7 & $20-349(330)$ & WP_026231793.1 & This work \\
\hline ScbA* & SCB49 unidentifiedbacterium & PL7 & 24-366 (343) & EDM45394.1 & This work \\
\hline
\end{tabular}

BAL1611. All seven coding sequences contain the codons from the original marine host [30]. The sequence for Atu3025 was amplified from genomic DNA from Agrobacterium tumefaciens C58. CDS for alyPEEC, algmsP, alyL1, a1-II, a1-II'Cat, Cly, Lpe, ScbA, and ScbB were codon optimized for $E$. coli bias and synthesized. N-terminal secretion signal peptides and lipoprotein signal peptides were predicted with SignalP 4.1 and LipoP 1.0, respectively, and were not included in the expression constructs $[49,50]$. All genes were PCR-amplified to add restriction sites and/or Gateway recombination sequences using primers from Table S1. Ligasebased cloning was performed for expression vectors pET22b+, pETDuet1, pMXB10, pTYB21, pN-HIS10, and pNative (see Table S2). The latter two vectors were constructed for this work using the pET22b+ backbone. pN-HIS10 has ten His codons before the NdeI site in pET22b+. pNative has a stop codon before the $\mathrm{XhoI}$ site in $\mathrm{pET} 2 \mathrm{~b}+$. All genes and expression vectors were digested with NdeI or AseI (towards start codon), and XhoI or SalI (towards the stop codon). NdeI/AseI and Xhol/SalI have compatible ends and were alternatively used depending on the presence of secondary restriction sites.

Gateway expression vectors pETG-10A, 20A, 30A, 40A, 41A, 50A, 52A and 60A (see Table S2) were obtained from the Protein Expression and Purification Facility, European Molecular Biology Laboratory, Heidelberg. Gateway LR cloning was performed using primers shown in Table S1 as previously described [51].
Their same nomenclature was maintained. Non-synthetic genes required the addition of $17 \mathrm{bp}$ attL1-T1 and $14 \mathrm{bp}$ attL2-T1 adapters by PCR before cloning. A second round of amplification was necessary to obtain the full $49 \mathrm{bp}$ attL1-T1 and attL2-T1 sites, which allowed for efficient LR recombination. All synthetic genes already included $17 \mathrm{bp}$ attL-T1 adapters, thus requiring a single PCR with one set of primers before gateway cloning (attL1-T1-For and attL2-T1-Rev primers).

All PCR amplifications were performed using the X7 highfidelity Pfu polymerase [52]. Synthetic genes and primers were purchased from Integrated DNA Technologies (USA). Restriction enzymes were acquired from New England Biolabs (USA). T4 ligase and Gateway LR Clonase II were obtained from Invitrogen (USA). Sequence confirmation was performed by Macrogen Inc. (Korea).

\section{Standard Expression Protocol}

The inoculation protocol was based on "Strategy 3" from [53]. After chemical transformation of the expression host, the complete mix was transferred to grow overnight in $7 \mathrm{ml} \mathrm{LB}$ liquid medium plus $100 \mu \mathrm{g} / \mathrm{ml}$ ampicillin and $34 \mu \mathrm{g} / \mathrm{ml}$ chloramphenicol (only ampicillin for BL21 (DE3) alone). The $\mathrm{OD}_{600}$ of the cultures were then recorded, and the expression cultures were inoculated to a 0.05 final $\mathrm{OD}_{600}$. Expression cultures consisted of $20 \mathrm{ml}$ of ZYM-5052 autoinduction medium [54] in $60 \mathrm{ml}$ Erlenmeyer flasks, 
grown at $25^{\circ} \mathrm{C}$, and $200 \mathrm{rpm}$ orbital shaking. The standard expression protocol also considered: BL21 (DE3) Rosetta2 as the host; harvesting at $42 \mathrm{~h}$, and expression vector pET22b+, unless otherwise stated.

\section{Preparation of Protein Crude Extracts}

Briefly, $2 \mathrm{ml}$ of the autoinduction cultures were centrifuged and resuspended in $600 \mu \mathrm{l}$ TBS $\mathrm{pH}$ 7.5. Samples were sonicated twice in Eppendorf tubes for $10 \mathrm{sec}$ each time, with a $1 / 8^{\prime \prime}$ tip at $8 \mathrm{~W}$ power using a XL-2000 sonicator (Misonix, USA). Samples were then centrifuged at $20,000 \mathrm{~g}$ for $10 \mathrm{~min}$ at $4^{\circ} \mathrm{C}$. The clear supernatant was then recovered and used for the enzymatic assays.

Enzymatic Assays for Testing Expression of Endo- and ExoAlginate Lyases

Recombinant protein production is reported as soluble alginate lyase activity in this work. All enzymatic assays were normalized to the same volume of original culture media loaded per reaction. For endo-lyases, $37.5 \mu \mathrm{l}$ of the soluble protein supernatants were mixed with $1 \mathrm{ml}$ of the reaction buffer: $50 \mathrm{mM}$ Tris- $\mathrm{HCl} \mathrm{pH} 8.0$, $0.5 \% \mathrm{w} / \mathrm{v}$ sodium alginate from brown algae (W201502, Sigma), $400 \mathrm{mM} \mathrm{NaCl}, 1 \mathrm{mM} \mathrm{CaCl}$. Reactions were incubated for $4 \mathrm{~h}$ at $30^{\circ} \mathrm{C}$ with $200 \mathrm{rpm}$ orbital shaking. For exo-lyase initial assays were performed using $50 \mu \mathrm{l}$ of the soluble protein supernatants mixed with $1 \mathrm{ml}$ of the reaction buffer: $50 \mathrm{mM}$ Tris- $\mathrm{HCl} \mathrm{pH} 7.5$, and $1 \% \mathrm{w} / \mathrm{v}$ sodium alginate from brown algae (Sigma). Reactions were incubated for $6 \mathrm{~h}$ at $30^{\circ} \mathrm{C}$ with $200 \mathrm{rpm}$ orbital shaking.

The resulting reducing sugar ends were then quantified with a microplate DNS assay using a glucose standard curve for comparing the amount of released oligoalginate reducing ends [55]. Absorbance was measured at $550 \mathrm{~nm}$ with a UVM 340 microplate reader (Asys, Eugendorf, Austria). Negative controls were always included containing the equivalent amount of soluble protein from the E. coli host without an expression plasmid incubated with the corresponding substrate.

\section{Enzymatic Assays for Testing Different Combinations of Exo/ Endo-Lyases}

Briefly, $50 \mu \mathrm{l}$ of exo-lyase and $37.5 \mu \mathrm{l}$ of endo-lyase crude protein preparations (Section 2.4) were incubated with $1 \mathrm{ml}$ of $0.5 \%$ alginate Tris- $\mathrm{HCl} \mathrm{pH} \mathrm{7.5,} \mathrm{for} 2 \mathrm{~h}$ at $30^{\circ} \mathrm{C}, 200 \mathrm{rpm}$ agitation. For the quantification of uronic acid reducing ends, $25 \mu \mathrm{l}$ of reaction products with $75 \mu \mathrm{l}$ of copper reagent were boiled for 10 min. Samples were incubated on ice for $5 \mathrm{~min}$, and $50 \mu \mathrm{l}$ of Nelson's reagent plus $100 \mu \mathrm{l}$ of distilled water were then added [56]. Each mixture was centrifuged at 2,600 $\mathrm{g}$ for $5 \mathrm{~min}$ and the absorbance of each sample was measured at $595 \mathrm{~nm}$ in a microplate reader (UVM340). A standard curve was prepared using glucuronic acid (Sigma).

\section{Statistical Analysis}

The results were subjected to one-way ANOVA analysis and
Tukey's HSD test $(p<0.05)$ for multiple comparison using Graph Pad Prism software.

\section{Enzymatic Reactions Using Algae Biomass}

Crude protein enzyme preparations were quantified using the Bio-Rad Bradford assay (USA). $0.3 \mathrm{mg}$ of total protein from the crude preparations of an exo and an endo-lyase $(0.6 \mathrm{mg}$ total protein) were loaded in each reaction containing $220 \mathrm{mg}$ of acidpretreated dry Macrocystis pyrifera biomass [25] in a final volume of $1.5 \mathrm{ml} 0.5 \mathrm{M}$ Tris- $\mathrm{HCl} \mathrm{pH}$ 7.5. The high concentration of Tris buffer was required due to the high acidity of the algal substrate. Duplicate reactions were incubated for $6 \mathrm{~h}$, at $30^{\circ} \mathrm{C}, 200 \mathrm{rpm}$ shaking, unless otherwise stated. Released uronic acid reducing ends were quantified as in Section 2.6.

\section{Thin Layer Chromatography (TLC)}

The plates of silica gel 60 F254 (Merck Millipore) were developed in n-butanol-acetic acid-water $(3: 2: 2(\mathrm{v} / \mathrm{v} / \mathrm{v}))$ for $4 \mathrm{~h}$, followed by drying of the plates. Reaction products were visualized with a sulfuric acid-ethanol (1:4 (v/v)).

\section{Results and Discussion}

\section{Selection of Alginate Lyase Targets}

Endo and exo-alginate lyases selected for this work are shown in Table 1, along with their sequence information and the corresponding primary references. Endo AlyA-D2, AlyB, AlyD, and Aly-SJ02 were selected because these enzymes were found suitable for alginate degradation and conversion into ethanol (E. coli strain BAL161) [30]. Only domain 2 of AlyA was cloned because it has been reported that the full protein is less active [42]. After a survey through the literature, additional genes coding for AlyPEEC, AlgmsP, AlyL1, A1-II, and A1-II'were selected for codon optimization and synthesis based primarily on reported $V_{\max }$, and the ability to cleave all three M-M, G-G, and M-G bonds. Selected enzymes belong primarily to polysaccharide lyase family 7 (PL7) according to the CAZy database. This family constitutes $39 \%$ of the total 1,618 enzymes classified so far among the seven alginate lyase families. Also the PL7 family constitutes $40 \%$ of the 91 alginate lyases characterized to date [57]. Enzymes within the PL7 family share the same $\beta$-jelly roll folding pattern and the disposition of the amino acid in the reaction center. The more recently classified PL18 family also shares these characteristics [58]. Endo-lyases from these two families are the subject of the present work in order to obtain results that could be useful for a broader range of research groups.

Most bacterial exo-alginate lyases are classified into families PL15 and PL17 [2]. There are only two examples of 
characterized PL7 exo-alginate lyases [27, 59]. PL7 exolyases are interesting because they are smaller than their PL15/PL17 counterparts, ranging between 300-400 amino acids in length versus the 700-800 residues of the latter. This might be beneficial for facilitating expression and folding in a heterologous host, while it also reduces the cost and complexity of gene synthesis. Given these advantages we decided to target this sub-type of enzymes for expression in E. coli. The sequence of Zobellia galactanivorans ALyA5 PL7 exo-alginate lyase was blasted against the NCBI database, and results were filtered to obtain a sub-set of enzymes with at least $95 \%$ sequence coverage and $55 \%$ sequence identity. A distance tree was generated based on pairwise alignments to AlyA5 using BLAST tree view default parameters. Five targets were selected, each one being a representative from different branches of the distance tree [60]. All five targets have the three loop insertions that are characteristic to the exo AlyA5 primary sequence and tertiary structure, which differentiates these enzymes from the PL7 endo-lyases (Fig. S1) [59]. Additionally, Atu3025, OalA, OalB, and OalCendo-lyases (oligoalginate lyases) were also selected for expression because they have been satisfactorily implemented for the saccharification of alginate [30, 61, 62].

\section{Optimization of Recombinant Expression Conditions}

All of the characterized enzymes from Table 1 have been previously expressed in E. coli, either in a soluble or insoluble form; therefore we maintained this expression platform in our experiments. Current methods for high-throughput protein expression have successfully implemented the T7 promoter and Studier autoinduction method, given the advantages of higher cell density upon induction, reduced sample manipulation and monitoring, and IPTG cost savings [54, 63]. This method can also be coupled with a simpler inoculation strategy, in which the transformed competent $E$. coli cells are directly grown in autoinduction media, without significant effects in protein yields [53]. The latter protocol considers autoinduction at $25^{\circ} \mathrm{C}$, which is in agreement with results obtained in an additional high-throughput survey for soluble recombinant expression in E. coli [64]. Since our target alginate lyases derive from marine bacteria, which thrive at temperatures below $37^{\circ} \mathrm{C}$, we set our standard protocol for autoinduction at $25^{\circ} \mathrm{C}$ for $42 \mathrm{~h}$, with 0.05 final $\mathrm{OD}_{600}$ inoculation density, as in [53]. The pET22b+ expression vector, with a C-terminal His-tag, was used for our standard protocol. The combination of the aforementioned strategies result in a streamlined protocol that was implemented for optimizing three critical parameters: expression host, protein fusion partner, and harvesting time.

High-throughput surveys have demonstrated that selection of an appropriate expression strain is a key parameter for recombinant protein production in E. coli $[63,64]$. Based on these results, four E. coli strains were selected because they allowed for soluble expression of the highest number of genes: Bl21 (DE3); BL21 (DE3) pLysS; BL21 (DE3) Rosetta2, and BL21 (DE3) pLysS Rosetta2, for expressing three alginate lyases (AlyA-D2, AlyB, and Aly-SJ02). Fig. S2 shows that strain selection can cause substantial differences in soluble alginate lyase expression, and that even enzymes from the same PL family, like AlyA and AlyB, may not express to similar levels with the same E. coli host. BL21 (DE3) Rosetta2 strain allowed for high soluble expression for all three enzymes, and it gives flexibility for expressing noncodon optimized genes, since it carries a plasmid with 7 rare tRNA [65]. Strains carrying the pLysS plasmid expressed the lowest levels of active enzyme, which could be due to the amidase activity of LysS lysozyme (cell wall degradation) and the T7 polymerase inhibition present in these hosts $[66,67]$.

Overexpression of proteins in E. coli often results in accumulation of inactive and insoluble aggregates, which require labor-intensive and low-efficiency refolding protocols. Addition of protein fusion-tags to the recombinant target can enhance solubility, while some of them also facilitate detection and purification [68]. In this study we used a set of 14 expression vectors (Table S2) for determining which fusion partners might yield the best accumulation of soluble and active enzyme using our standard expression protocol in BL21 (DE3) Rosetta2. We expressed the same three alginate lyases from the above experiments with all 14 tags, and the enzyme activity results are shown in Fig. S3. All three targets expressed well without the addition of a tag, which is indicative of the soluble nature of alginate lyases. The proteins still expressed well with the addition of an $\mathrm{N}$-, or C-terminal Histidine tag, which might constitute a viable alternative for detecting and purifying alginate lyases. The three best vectors were: pETG40A, 41A, and 60A. pETG40A and pETG41A have an N-terminal maltose-binding protein (MBP), without or with a 6xHistag, respectively. pETG60A has an N-terminal $\mathrm{N}$ utilization substance protein A tag (NusA) along with a 6xHis-tag. These results are in agreement with previous large protein expression surveys [64]. In contrast, our results also show that some tags should probably be avoided for alginate lyase expression, like N-terminal Sce VMA chitin-bindingdomain/intein (pTYB21), and N-terminal His-tag/Glutathione 
S-transferase (pETG30).

It was noticed that culture density reached saturation before the $42 \mathrm{~h}$ autoinduction time proposed by [53], given the high inoculation density employed by these authors $\left(0.05\right.$ final $\left.\mathrm{OD}_{600}\right)$. Therefore, we analyzed the effect of shorter autoinduction times, while maintaining this inoculation level, which could ultimately result in higher protein yields, shorter experiments, and lower overall production costs. A preliminary screening with autoinduction of AlyA-D2, AlyB, and Aly-SJ02 at $25^{\circ} \mathrm{C}$ showed that harvesting at $23 \mathrm{~h}$ generated higher alginate lyase activity compared to longer culture times (data not shown). Therefore, the same three strains were sampled every three hours between 8 and $20 \mathrm{~h}$ of culture time, and the recombinant enzyme activity results are shown in Fig. S4. It is apparent that harvesting at 8 or $11 \mathrm{~h}$ results in very low enzyme yields. It is likely that glucose, the expression repressor, is depleted from the autoinduction medium between 8 and $11 \mathrm{~h}$, thus triggering the accumulation of the recombinant proteins past $11 \mathrm{~h}$. All three enzyme activities reached a peak at $14 \mathrm{~h}$ after inoculation. AlyA-D2 and AlySJ02 activities start diminishing after $17 \mathrm{~h}$, while AlyB activity increases slightly between 14 and $20 \mathrm{~h}$. These different trends are most likely related to the stability of each enzyme under these culture conditions, and their sensitivity towards the host proteases.

\section{Optimized Protocol for the Expression of Additional Alginate Lyases}

An optimized protocol has been generated for testing the expression of all alginate lyases targets from Table 1 . The following conditions were implemented:

\section{- E. coli BL21 (DE3) Rosetta2}

- Expression vectors pNative, pETG41A, or pETG60A

- ZYM-5052 autoinduction medium

- 0.05 final $\mathrm{OD}_{600}$ inoculation, $14 \mathrm{~h}$ harvesting time at $25^{\circ} \mathrm{C}, 200 \mathrm{rpm}$

Results are shown in Fig. 1. The proposed protocol allowed us to express eight out of nine alginate endolyases, and three out of nine exo-lyases. The process only takes $14 \mathrm{~h}$ of culture time at $25^{\circ} \mathrm{C}$, which could prove favorable when taking into account energy costs of the fermentation. The enzyme extract was normalized to $0.3 \mathrm{mg}$ of total protein for each type of lyase. The overall results suggest the conclusion that $\mathrm{N}$-terminal $6 \mathrm{xHis- \textrm {MBP }}$ is the partner of choice for expressing endo-lyases, while no partner seems to be the best option for exo-lyases.

Endo A1-II' was the only enzyme that strictly required
A apNative $\square$ pETG41A apETG60A
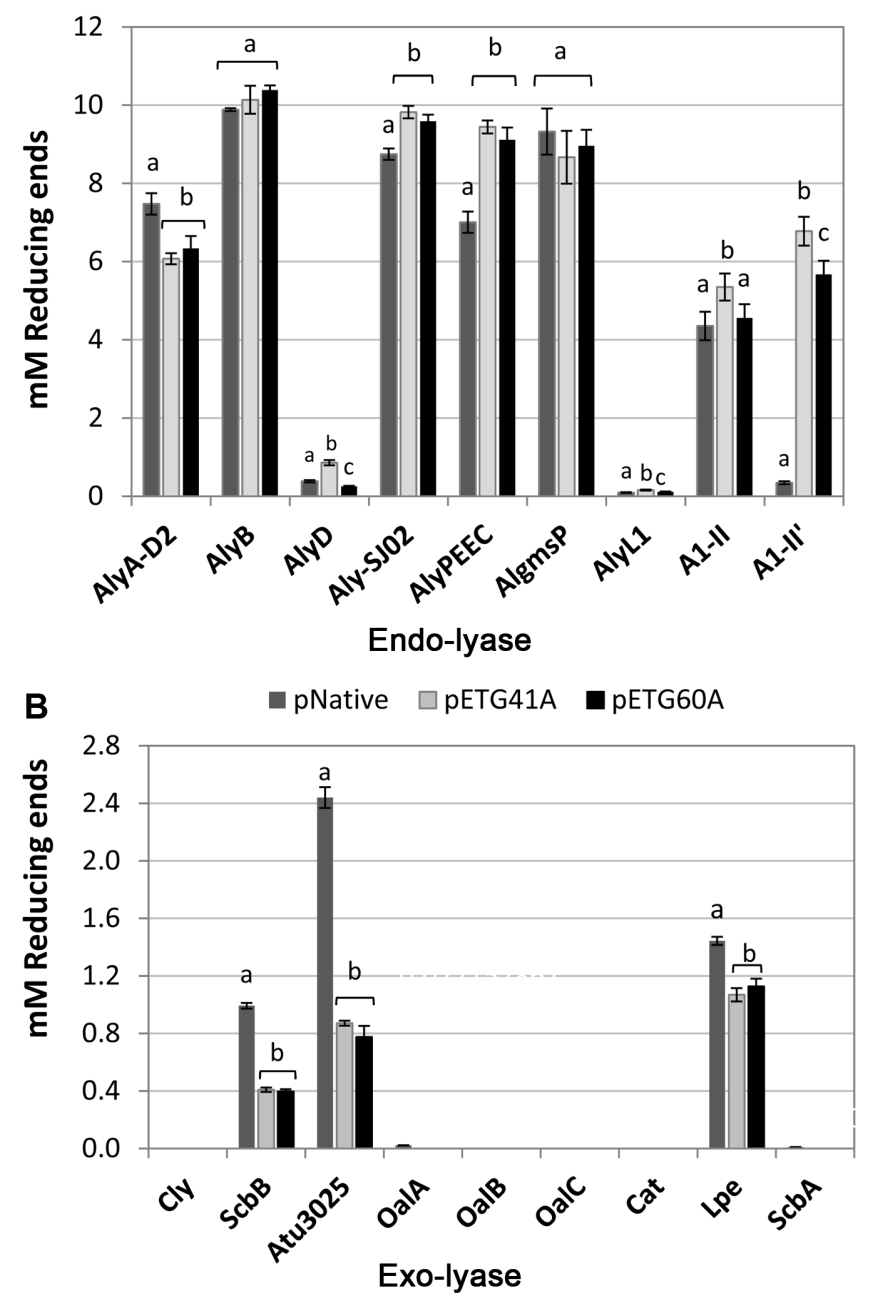

Fig. 1. Optimized protocol for the expression of 18 different alginate lyases in E. coli.

Three different vectors were tested using the parameters from Section 2.3. (A) Endo-lyase targets. (B) Exo-lyase targets. Enzymatic assays were performed as described in Materials and Methods. Plasmid pNative: no tag fused to the target protein; pETG41A: N-terminal 6xHis/Maltose-binding protein tag; pETG60A: N-terminal NusA/ 6xHis tag. Error bars represent the standard deviation of duplicates. For each enzyme mixture, means with different letters are significantly different (Tukey's HSD, $p<0.05$ ).

the presence of a fusion partner for soluble expression, probably for enhancing folding and/or solubility. Endo AlyA-D2, and the three exo-lyases (Atu3025, Lpe, and $\mathrm{ScbB}$ ) had the highest activity when expressed in the native form. This could be related to negative steric effects on enzyme function caused by the exogenous fused polypeptide. This in turn could be alleviated by adding a protease site for cleaving the fusion partner, or by 


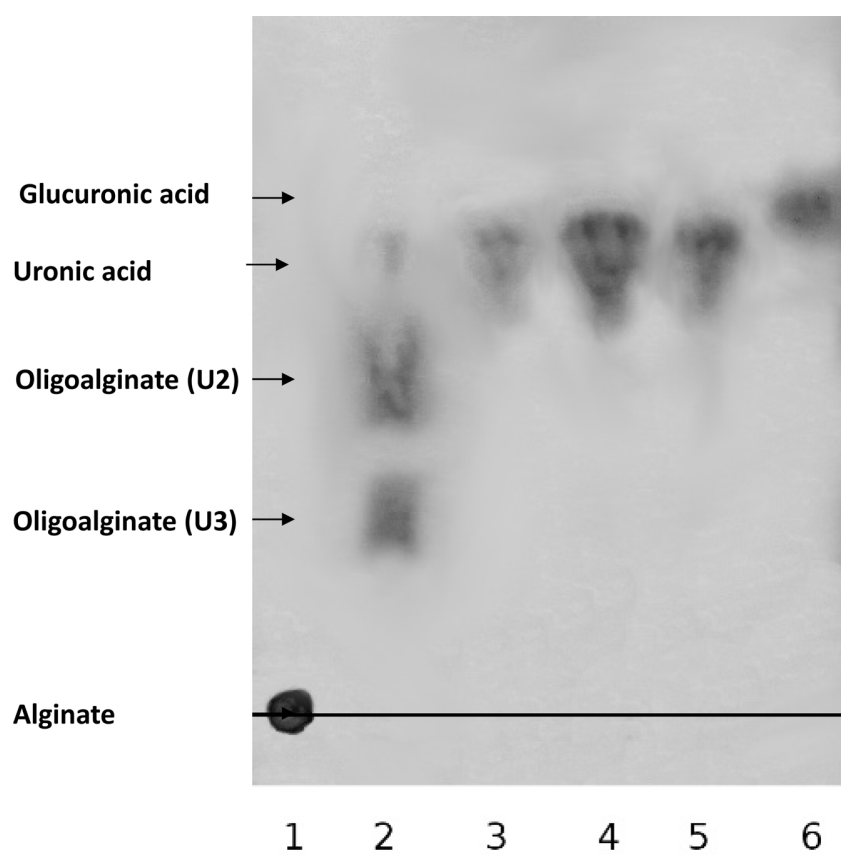

Fig. 2. Thin-layer chromatography of the hydrolysis products of alginate.

Lane 1, alginate + no enzymes; Lane 2, endo-Aly-SJ02; Lane 3, endoAly-SJ02 + exo-Lpe; Lane 4, endo-Aly-SJ02 + exo-ScbB; Lane 5, endoAly-SJ02 + exo-Atu3025; Lane 6, glucuronic acid standard. Reactions were prepared as in Section 2.6. $8 \mu \mathrm{l}$ of each reaction ( $0.5 \%$ alginate) and standard $(1 \mathrm{mg} / \mathrm{ml})$ were loaded per lane.

including an optimized peptide linker sequence.

Additionally, different $\mathrm{pHs}$ for all expressed targets based on the literature were tested (data not shown), and the ones utilized in this paper represent conditions that work well with all enzymes.

\section{Confirmation of Exo-Lyase Activity of ScbB and Lpe}

Thin-layer chromatography was performed in order to confirm the release of urinate monomers due to the exolyase activity of the novel enzymes ScbB and Lpe. Fig. 2 shows that alginate is degraded into a mixture of oligoalginates in the presence of the Aly-SJ02 endo-lyase by itself (Lane 2). When combined with Atu3025, a confirmed exo-lyase, the alginate degradation products resolved into a shorter band (Lane 5), with a size similar to the glucuronate monomer (Lane 6). Lanes 3 and 4 show a product of similar size as in Lane 5, without the detectable presence of larger oligoalginates, confirming that Lpe and ScbB have exo-lyase activity. These results support that the unique sequence and structural characteristics of Z. galactanivorans ALyA5 PL7 exo-alginate lyase could be valuable for predicting exo-lyase activity in PL7-like enzymes (Fig. S1) [59].

\section{Alginate Saccharification Using a Combinatorial Approach \\ Seven recombinant endo-lyase preparations were combined} with three exo-lyase extracts, resulting in 21 enzyme cocktails for the saccharification of alginate. Table 2 shows the product yields from the saccharification of purified alginate using these 21 combinations along with controls containing the endo-lyases by themselves. When comparing the overall results for the three exo-lyases, it is apparent that ScbB yielded the lowest amounts of reducing sugar ends. On the other hand, Atu3025 and Lpe produced overall higher yields, and behaved similarly with the corresponding endo-lyases. Interestingly the endo-lyase partner that resulted in the highest yields for ScbB (AlgmsP) was the least efficient partner for Atu3025 and Lpe. Conversely, the better suited partners for Atu3025 and Lpe (AlyPEEC and Aly-SJ02, respectively) resulted in low product yields for ScbB. Moreover, the endo-lyase that resulted in the lowest yield for ScbB (AlyB), produced high quantities of reducing ends with Atu3025 and Lpe. Additionally, A1-II' endo-lyase was one of most productive

Table 2. Degradation of purified alginate using 21 combinations of endo- and exo-alginate lyases.

\begin{tabular}{lcccc}
\hline & Exo-Lyase & & \\
\hline Endo-Lyase & ScbB & Atu3025 & Lpe & No Exo-Lyase \\
\hline AlyA-D2 & $0.072 \pm 0.020$ & $0.538 \pm 0.035$ & $0.545 \pm 0.031$ & $0.011 \pm 0.002$ \\
AlyB & $0.059 \pm 0.010$ & $0.523 \pm 0.034$ & $0.579 \pm 0.017$ & $0.093 \pm 0.021$ \\
Aly-SJ02 & $0.226 \pm 0.012$ & $0.578 \pm 0.093$ & $0.679 \pm 0.044$ & $0.075 \pm 0.005$ \\
AlyPEEC & $0.195 \pm 0.002$ & $0.612 \pm 0.056$ & $0.552 \pm 0.077$ & $0.032 \pm 0.001$ \\
AlgmsP & $0.342 \pm 0.012$ & $0.390 \pm 0.047$ & $0.382 \pm 0.036$ & $0.137 \pm 0.025$ \\
A1-II & $0.140 \pm 0.042$ & $0.490 \pm 0.032$ & $0.427 \pm 0.051$ & $0.076 \pm 0.035$ \\
A1-II' & $0.297 \pm 0.002$ & $0.455 \pm 0.032$ & $0.558 \pm 0.004$ & $0.173 \pm 0.044$ \\
\hline
\end{tabular}

The mean values correspond to the equivalent of $\mathrm{mg} / \mathrm{ml}$ of glucuronic acid as the standard represents the standard deviation of duplicates. Samples were prepared as described in Materials and Methods. 
partners for ScbB and Lpe, while at the same time was one of the least proficient partners for Atu3025. The relative inconsistency for any single enzyme to produce the highest yields is indicative of interdependency between the endo and exo type of enzymes. This is probably due to the substrate bias that is characteristic for a given alginate lyase. Oligoalginates produced by endo-lyases differ in length and $\mathrm{G} / \mathrm{M}$ bond composition depending on the specific enzyme. Some oligoalginates would be substrates with higher affinity for some specific endo-lyases, which also have biases for length and glycosidic bond composition [2]. Therefore it is important to find an optimal couple of enzymes for a particular process and biomass, and to do this it is necessary to produce a wide array of targets, such as the ones presented for the first time in this work. Additionally, it is also important to match enzymes according to their optimum temperature, $\mathrm{pH}$ and buffer composition. Fortunately most of characterized alginate lyases are produced by bacteria from marine environments, and have similar requirements [5]. Furthermore, an optimal couple of enzymes for one algal biomass might not be necessarily the best for other algae species. It is well documented that each species has a unique $G / M$ composition, which can also vary according to age, morphology of the alga, geographical location, and harvest season [4]. Finally, the possibility of using more than one endo and/or exo lyase per reaction should not be discarded. This notion is supported by the presence of several of these genes in a single organism. For example,

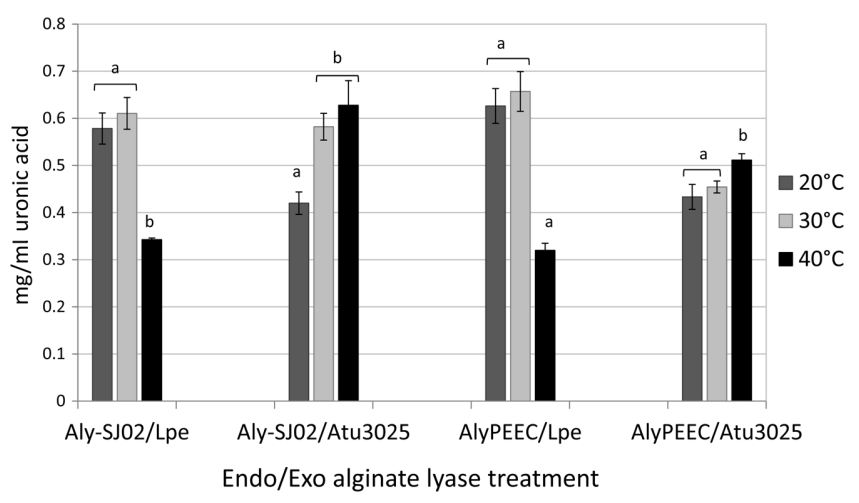

Fig. 3. Endo+Exo alginate lyase treatment of algal biomass at three different temperatures.

Acid pre-treated alga was incubated for $6 \mathrm{~h}$ and $200 \mathrm{rpm}$ at the indicated temperatures. Reactions contained: $0.3 \mathrm{mg}$ of total soluble protein crude extract for each enzyme, $220 \mathrm{mg}$ alga, in $1.5 \mathrm{ml}$ final volume of $0.5 \mathrm{M} \mathrm{pH}$ 7.5 Tris buffer. Error bars represent the standard deviation of duplicates. For each enzyme mixture, means with different letters are significantly different (Tukey's HSD, $p<0.05$ ). the well-studied Vibrio splendidus 12B01 has 4 functional endo-lyases and 3 exo-lyases [42, 61].

\section{Activity of Alginate Lyase Pairs at Different Temperatures}

According to the product yield results from Table 2, four alginate lyase pairs were selected for further testing: AlySJ02/Lpe, Aly-SJ02/Atu3025, AlyPEEC/Lpe, and AlyPEEC/ Atu3025. Fig. 3 shows the results from treating M. pyrifera biomass (brown algae) for $6 \mathrm{~h}$ at three different temperatures: $20^{\circ} \mathrm{C}, 30^{\circ} \mathrm{C}$, and $40^{\circ} \mathrm{C}$. This incubation time was selected in order to favor enzymes that are thermally stable over time, so they continue to catalyze the reaction. These temperatures were selected because most alginate lyases are derived from marine bacteria, and are active at $20^{\circ} \mathrm{C}$ or less, although they usually achieve maximum activity between $30^{\circ} \mathrm{C}$ and $40^{\circ} \mathrm{C}[2,5]$. None of the enzyme combinations performed best at $20^{\circ} \mathrm{C}$. Incubation at $40^{\circ} \mathrm{C}$ marginally favored AlyPEEC/Atu3025, while not having a relevant effect for Aly-SJ02/Atu3025 when compared to the yield at $30^{\circ} \mathrm{C}$. On the other hand, pairs containing Lpeexo-lyase were negatively affected by the highest incubation temperature, indicating that this enzyme might be unstable at $40^{\circ} \mathrm{C}$. Overall, incubations at $30^{\circ} \mathrm{C}$ yielded consistently higher product accumulation for all four enzyme couples, therefore this temperature was used for subsequent experiments. These results are in accordance with the optimal temperature range for many characterized alginate lyases from marine bacteria [5].

\section{Effect of Endo/Exo Lyase Load Ratio on Product Yield}

It is expected that the endo and exo lyases will not catalyze their respective reactions at the same rate for a given pair of enzymes. It is also likely that one of the enzymes could be more stable over time than the other. It is then necessary to test if adding different proportions of endo and exo lyase would affect the final product yield. Fig. 4 shows the results from the saccharification of algal biomass using four different endo/exo lyase enzyme loads: $1: 1,1: 3,3: 1$, and 3:3. A $1 \mathrm{X}$ enzyme load corresponds to $0.3 \mathrm{mg}$ of total soluble protein from the crude E. coli extract for each enzyme. It is apparent from this Figure that the reactions are close to being saturated by a 1:1 enzyme load for the four enzyme cocktails. There are no clear advantages to adding three times more endo-lyase for any of the enzyme combinations. Furthermore, in some cases the extra endolyase load caused a reduction in product yield. This might be due to the inhibition of the reaction by all the additional impurities present in the E. coli crude extract. This can be directly observed in Fig. S5, which shows that the addition 


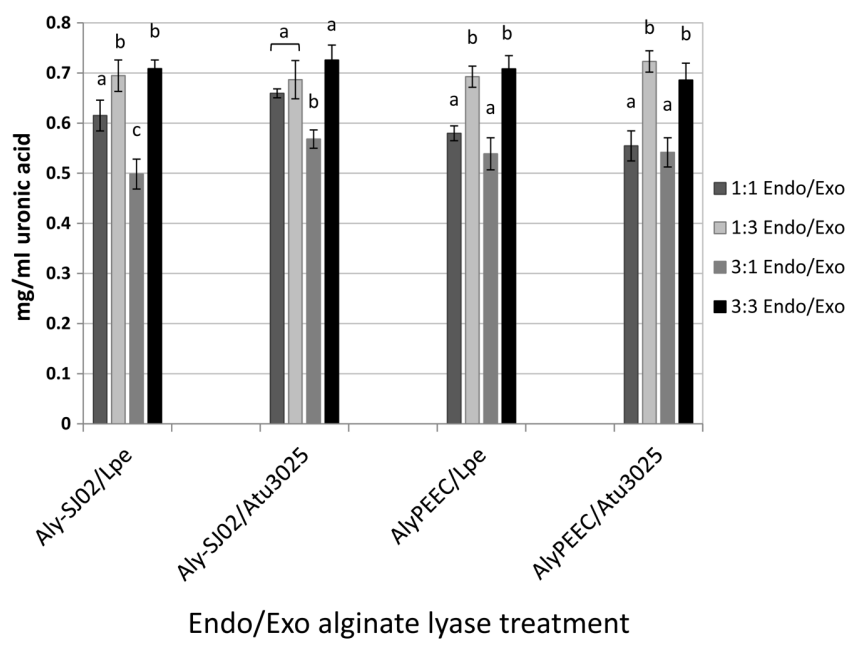

Fig. 4. Effect of exo/endo enzyme load ratio on alginate saccharification.

A $1 \mathrm{X}$ enzyme load corresponds to $0.3 \mathrm{mg}$ of total protein from the crude extracts. Each reaction contained $220 \mathrm{mg}$ of alga in $1.5 \mathrm{ml}$ final volume of $0.5 \mathrm{M} \mathrm{pH} 7.5$ Tris buffer. Treatment was performed for $6 \mathrm{~h}$, $30^{\circ} \mathrm{C}, 200 \mathrm{rpm}$. Error bars represent the standard deviation of duplicates. For each enzyme mixture, means with different letters are significantly different (Tukey's HSD, $p<0.05$ ).

of $0.6 \mathrm{mg}$ total protein of an untransformed E. coli extract causes the reduction of product yield for a 1:1 enzyme load. For this reason, and since the endo-lyase reactions seem to have excess catalyst, it is plausible to think that a higher product yield might be achieved by loading less crude extract for certain endo-lyases. On the other hand, the reactions were not negatively affected by a 1:3 or 3:3 endo/ exo ratios when compared to the $1: 1$ ratio, leading us to think that the additional exolytic activity countered the inhibitory effects of the crude extracts. Only in the case of reactions containing AlyPEEC was there an advantage from adding three times more exo-lyase than endo-lyase (20\% product increase). A 1:3 enzyme ratio was maintained for our final enzyme trials since it did not result in lower product yields for any of the cocktails and was superior for the ones containing AlyPEEC when compared to a 1:1 ratio.

\section{Exo-Alginate Lyase Loading Strategy into the Reaction}

It has been shown that loading an alginate exo-lyase after the endo-lyase has generated most of the oligoalginates results in higher product yields when compared to simultaneous addition of both enzymes [24]. We therefore compared these two strategies with our four enzyme couples to test whether this behavior was enzymedependent (Fig. 5). Incubations were carried out for $9 \mathrm{~h}$,
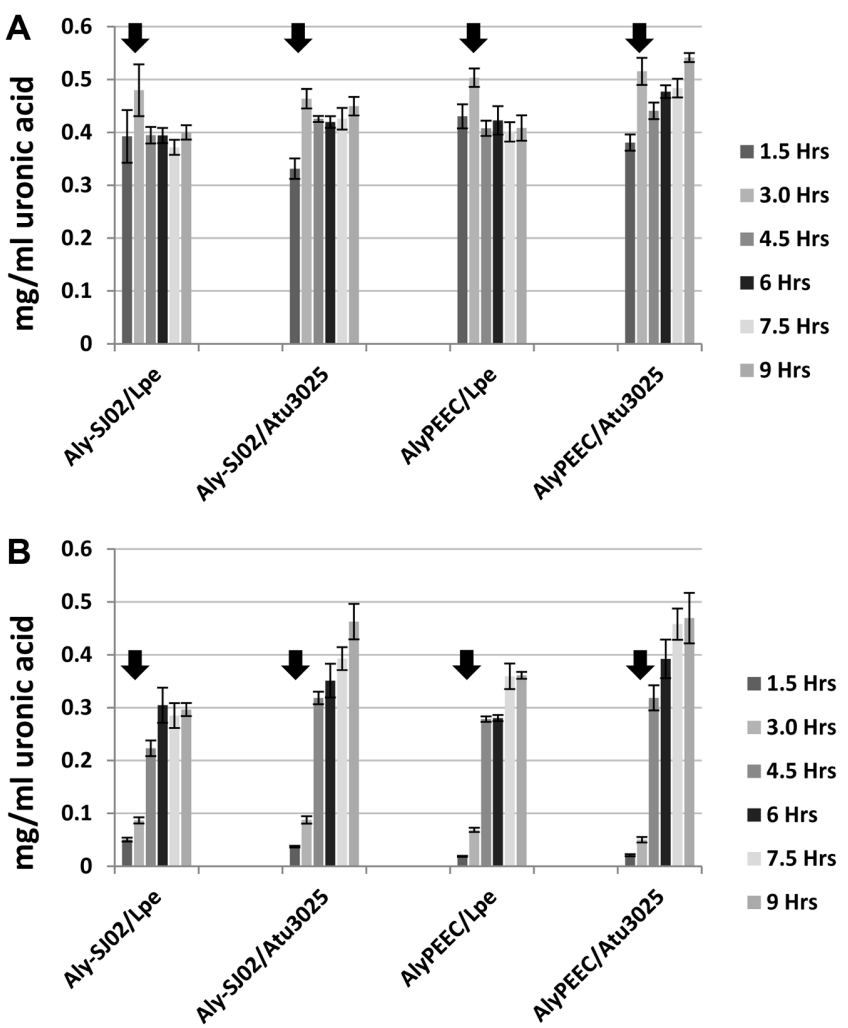

Fig. 5. Simultaneous versus sequential enzyme loading strategies.

(A) $0.3 \mathrm{mg}$ of total protein from exo and endo-lyase preparations were simultaneously loaded at the beginning of the experiments. (B) $0.3 \mathrm{mg}$ total protein from the endo-lyase preparations were loaded at time point $0 \mathrm{~h}$; the same amount of exo-lyase preparations were loaded after time point $3 \mathrm{~h}$. The black arrows indicate at which point the exo-lyases were added. In the case of the simultaneous strategy (A), the arrows indicate that the reactions were diluted with an equivalent volume of buffer instead of the exo-lyase preparations. Reactions contained $220 \mathrm{mg}$ of acid-treated alga in an initial volume of $1.5 \mathrm{ml}, 0.5 \mathrm{M}$ Tris pH 7.5 buffer, incubated at $30^{\circ} \mathrm{C}, 200 \mathrm{rpm} .100 \mu \mathrm{l}$ samples were withdrawn every $1.5 \mathrm{~h}$ for uronic acid quantification. Error bars represent the standard deviation of duplicates.

with samples withdrawn every $1.5 \mathrm{~h}$. Exo-lyases were added after $3 \mathrm{~h}$ in sequential loading experiments (Fig. 5B), at that point reactions for simultaneous enzyme load were also diluted by an equivalent volume (approximately 25\% volume increase). The latter explains the reduction in product concentration from time point 3 to $4.5 \mathrm{~h}$ in Fig. 5A. At the end of the experiments, three of the enzyme pairs generated more product when the lyases were added simultaneously when compared to sequentially (13-35\% yield increase). Only Aly-SJ02/Atu3025 responded with a marginal decrease in yield when the enzymes were added 
simultaneously. These trends seem to be in contrast with results from [24]. However these authors tested only one enzyme couple in which the exo-lyase was unstable at their reaction conditions $\left(40^{\circ} \mathrm{C}\right)$. A sequential strategy is beneficial in this case because the oligoalginates produced by the endo-lyase will be present at high concentration when the unstable exo-lyase is added to the reaction. Given the results from Fig. 3, it is likely that the exo-lyases tested in our work are stable at $30^{\circ} \mathrm{C}$, therefore an advantage was observed when they were added along with the endolyases at the beginning of the reaction. Fig. 5 also shows that simultaneous enzyme load allowed attainment of maximum product yield at earlier time points for three of the cocktails (4.5 h), while AlyPEEC/Atu3025 reached the highest accumulation after $9 \mathrm{~h}$. Sequential load experiments reached their maximum yield at 7.5-9 h, except for AlySJ02/Lpe, which peaked at $4.5 \mathrm{~h}$. Shortened reaction times were also attained by [24] with a simultaneous enzyme load strategy.

Brown algae biorefineries hold great potential for the sustainable production of biofuels and bioactive ingredients. However there are no enzymatic tools for pilot scale work for enhancing the extraction and saccharification processes for phaeophytes. Even at the laboratory scale, there is limited availability of commercial alginate lyases for algae biotechnology. The present study has expanded the available repertoire of alginate lyases, while at the same time demonstrating that they can be easily expressed and implemented for everyday laboratory work. Moreover, this work has shown that testing a wide array of exo/endo alginate lyases can lead to enhanced saccharification results for a given biomass, probably due to the differences in substrate biases of these enzymes. Having several enzyme options would also prove valuable for allowing more flexibility when designing extraction processes from algal biomass from different species. Likewise, lyases could be selected based on the temperature and/or $\mathrm{pH}$ conditions from a previous step in the process in order to save time and costs. It was also demonstrated that shorter reaction times could be implemented with at least four different exo/endo lyase combinations when these enzymes were added simultaneously. This was in contrast with previous results showing an advantage when a thermally unstable exo-lyase is added after the oligoalginates have been released by the endo-lyase [24]. The latter disparity pinpoints the importance of working with enzymes that are stable in the reaction conditions, and has direct impact on the design of time-efficient algal degradation processes.

\section{Acknowledgments}

This work was supported by Comision Nacional de InvestigacionCientifica y Tecnologica CONICYT, Chile: [Grant AKA-ERNC 009 PROJECT] and [Centre for Biotechnology and Bioengineering, CEBIB FB-0001]. Our thanks to Dr. Julia Rossmanith, Dr. Hueseyin Besir, Dr. Arie Geerlof, and the Protein Expression and Purification Facility, EMBL, Heidelberg, for facilitating the Gateway expression vectors utilized in this study.

\section{Conflict of Interest}

The authors have no financial conflicts of interest to declare.

\section{References}

1. Draget KI, Smidsrød O, Skjåk-Bræk G. 2005. Alginates from Algae, In: Biopolymers Online. WileyVCH Verlag $\mathrm{GmbH} \&$ Co. KGaA. doi:10.1002/3527600035.bpol6008.

2. Zhu B, Yin H. 2015. Alginate lyase: review of major sources and classification, properties, structure-function analysis and applications. Bioengineered 6: 125-131.

3. Remminghorst U, Rehm B. 2006.Bacterial alginates: from biosynthesis to applications. Biotechnol. Lett. 28: 1701-1712.

4. Sari-Chmayssem N, Taha S, Mawlawi H, Guégan JP, Jeftić J, Benvegnu T. 2016. Extracted and depolymerized alginates from brown algae Sargassum vulgare of Lebanese origin: chemical, rheological, and antioxidant properties. J. Appl. Phycol. 28: 1915-1929.

5. Wong TY, Preston LA, Schiller NL. 2000. Alginate lyase: review of major sources and enzyme characteristics, structurefunction analysis, biological roles, and applications. Апnи. Rev. Microbiol. 54: 289-340.

6. Wang Y, Han F, Hu B, Li J, Yu W. 2006. In vivo prebiotic properties of alginate oligosaccharides prepared through enzymatic hydrolysis of alginate. Nutrit. Res. 26: 597-603.

7. Courtois J. 2009. Oligosaccharides from land plants and algae: production and applications in therapeutics and biotechnology. Curr. Opin. Microbiol. 12: 261-273.

8. Yonemoto Y, Tanaka H, Yamashita T, Kitabatake N, Ishida Y, Kimura A, et al. 1993 Promotion of germination and shoot elongation of some plants by alginate oligomers prepared with bacterial alginate lyase.J. Ferment. Bioeng. 75: 68-70.

9. Hu X, Jiang X, Hwang H, Liu S, Guan H. 2004. Promotive effects of alginate-derived oligosaccharide on maize seed germination. J. Appl. Phycol. 16: 73-76.

10. Iwasaki KI, Matsubara Y. 2000. Purification of alginate oligosaccharides with root growth-promoting activity toward lettuce. Biosci. Biotechnol. Biochem. 64: 1067-1070. 
11. Kawada A,Hiura N, Tajima S, Takahara H. 1999.Alginate oligosaccharides stimulate VEGF-mediated growth and migration of human endothelial cells. Arch. Dermatol. Res. 291: 542-547.

12. Yamamoto Y, Kurachi M, Yamaguchi K, Oda T. 2007. Stimulation of multiple cytokine production in mice by alginate oligosaccharides following intraperitoneal administration, Carbohydr. Res. 342: 1133-1137.

13. Iwamoto M, Kurachi M, Nakashima T, Kim D, Yamaguchi K, Oda $\mathrm{T}$, et al. 2005. Structure-activity relationship of alginate oligosaccharides in the induction of cytokine production from RAW264. 7 cells. FEBS Lett. 579: 4423-4429.

14. Kurachi M, Nakashima T, Miyajima C, Iwamoto $Y$, Muramatsu T, Yamaguchi K, et al. 2005.Comparison of the activities of various alginates to induce TNF- $\alpha$ secretion in RAW264. 7 cells. J. Infect. Chemother. 11: 199-203.

15. Khan S, Tøndervik A, Sletta H, Klinkenberg G, Emanuel C, Onsøyen E, et al. 2012. Overcoming drug resistance with alginate oligosaccharides able to potentiate the action of selected antibiotics. Antimicrob. Agents Chemother. 56: 5134-5141.

16. Powell LC, Sowedan A, Khan S, Wright CJ, Hawkins K, Onsøyen E, et al. 2013. The effect of alginate oligosaccharides on the mechanical properties of Gram-negative biofilms. Biofouling 29: 413-421.

17. Roberts JL, Khan S, Emanuel C, Powell LC, Pritchard M, Onsøyen E, et al. 2013. An in vitro study of alginate oligomer therapies on oral biofilms. J. Dent. 41: 892-899.

18. Yan G, Guo Y, Yuan J, Liu D, Zhang B. 2011. Sodium alginate oligosaccharides from brown algae inhibit Salmonella Enteritidis colonization in broiler chickens. Poult. Sci. 90: 1441-1448.

19. Alkawash MA, Soothill JS, Schiller NL. 2006. Alginate lyase enhances antibiotic killing of mucoid Pseudomonas aeruginosa in biofilms. Apmi 114: 131-138.

20. Islan GA, Bosio VE, Castro GR. 2013. Alginate lyase and ciprofloxacin co-immobilization on biopolymeric microspheres for cystic fibrosis treatment. Macromol. Biosci. 13: 1238-1248.

21. Hatch R, Schiller N. 1998. Alginate lyase promotes diffusion of aminoglycosides through the extracellular polysaccharide of mucoid Pseudomonas aeruginosa. Antimicrob. Agents Chemother. 42: 974-977.

22. Camus C, Ballerino P, Delgado R, Olivera-Nappa A, Leyton C, Buschmann AH. 2016. Scaling up bioethanol production from the farmed brown macroalga Macrocystis pyrifera in Chile. Biofuel Bioprod. Biorefin 10: 673-685.

23. Enquist-Newman M, Faust AME, Bravo DD, Santos CNS, Raisner RM, Hanel A, et al. 2014. Efficient ethanol production from brown macroalgae sugars by a synthetic yeast platform. Nature 505:239-243.

24. Kim HT, Yun EJ, Kim DH, Park YC, Woo HC, Kim KH. 2014. Optimal production of 4-deoxy-L-erythro-5-hexoseulose uronic acid from alginate for brown macro algae saccharification by combining endo-and exo-type alginate lyases. Bioprocess
Biosyst. Eng. 37: 2105-2111.

25. Ravanal MC, Pezoa-Conte R, von Schoultz S, Hemming J, Salazar O, Anugwom I, et al. 2016. Comparison of different types of pretreatment and enzymatic saccharification of Macrocystis pyrifera for the production of biofuel. Algal. Res. 13:141-147.

26. Ryu M, Lee EY. 2011. Saccharification of alginate by using exolytic oligoalginate lyase from marine bacterium Sphingomonas sp. MJ-3. J. Ind. Eng. Chem. 17: 853-858.

27. Takagi T, Yokoi T, Shibata T, Morisaka H, Kuroda K, Ueda M. 2016. Engineered yeast whole-cell biocatalyst for direct degradation of alginate from macroalgae and production of non-commercialized useful monosaccharide from alginate. Appl. Microbiol. Biot. 100: 1723-1732.

28. Takeda H, Yoneyama F, Kawai S, Hashimoto W, Murata K. 2011. Bioethanol production from marine biomass alginate by metabolically engineered bacteria. Energ. Environ. Sci. 4: 2575-2581.

29. Vanegas C, Hernon A, Bartlett J. 2015. Enzymatic and organic acid pretreatment of seaweed: effect on reducing sugars production and on biogas inhibition. Int. J. Ambient. Energy 36: 2-7.

30. Wargacki AJ, Leonard E, Win MN, Regitsky DD, Santos CNS, $\mathrm{Kim} \mathrm{PB}$, et al. 2012. An engineered microbial platform for direct biofuel production from brown macroalgae. Science 335: 308-313.

31. Alvarado-Morales M, Gunnarsson IB, Fotidis IA, Vasilakou E, Lyberatos G, Angelidaki I. 2015. Laminaria digitata as a potential carbon source for succinic acid and bioenergy production in a biorefinery perspective. Algal. Res. 9: 126-132.

32. Hou X, Hansen JH, Bjerre AB. 2015. Integrated bioethanol and protein production from brown seaweed Laminaria digitata. Bioresour. Technol. 197: 310-317.

33. Manns D, Andersen SK, Saake B, Meyer AS. 2016a. Brown seaweed processing: enzymatic saccharification of Laminaria digitata requires no pre-treatment. J. Appl. Phycol. 28: 1287-1294.

34. Manns D, Nyffenegger C, Saake B,Meyer AS. 2016b. Impact of different alginate lyases on combined cellulase-lyase saccharification of brown seaweed. RSC Adv. 6: 45392-45401.

35. Sharma S, Horn SJ. 2016. Enzymatic saccharification of brown seaweed for production of fermentable sugars. Bioresour. Technol. 213: 155-161.

36. Ravanal MC, Sharma S, Gimpel J, Reveco-Urzua F, Øverland M, Horn SJ, et al. 2017. The role of alginate lyases in the enzymatic saccharification of brown macroalgae, Macrocystis pyrifera and Saccharina latissima. Algal. Res. 26: 287-293.

37. Deniaud-Bouët E, Kervarec N, Michel G, Tonon T, Kloareg B, Hervé C. 2014. Chemical and enzymatic fractionation of cell walls from Fucales: insights into the structure of the extracellular matrix of brown algae. Ann. Bot. 114: 1203-1216.

38. Hafting JT, Craigie JS, Stengel DB, Loureiro RR, Buschmann AH, Yarish C, et al. 2015. Prospects and challenges for industrial 
production of seaweed bioactives. J. Phycol. 51: 821-837.

39. Lakmal HC, Lee JH, Jeon YJ. 2015. Enzyme-assisted extraction of a marine algal polysaccharide, fucoidan and bioactivities in Polysaccharides: Bioactivity and Biotechnology. (Ed Ramawat KG and Mérillon J-M) 1065-1077.

40. Leyton A, Pezoa-Conte R, Barriga A, Buschmann A, Mäki-Arvela P, Mikkola JP, et al. 2016. Identification and efficient extraction method of phlorotannins from the brown seaweed Macrocystis pyrifera using an orthogonal experimental design. Algal. Res. 16: 201-208.

41. Yamasaki M, Moriwaki S, Miyake O, Hashimoto W, Murata K, Mikami B. 2004. Structure and Function of a Hypothetical Pseudomonas aeruginosa Protein PA1167 Classified into Family PL-7 a novel alginate lyase with a $\beta$-sandwich fold. J. Biol. Chem. 279: 31863-31872.

42. Badur AH, Jagtap SS, Yalamanchili G, Lee JK, Zhao H, Rao CV. 2015. Characterization of the alginate lyases from Vibrio splendidus 12B01. Appl. Environ. Microb. 03460-03414.

43. Li JW, Dong S, Song J, Li CB, Chen XL, Xie BB, Zhang YZ. 2011. Purification and characterization of a bifunctional alginate lyase from Pseudoalteromonas sp. SM0524. Mar. Drugs 9: $109-123$

44. Ma L, Chi Z, Li J, Wu L. 2008. Overexpression of alginate lyase of Pseudoalteromonas elyakovii in Escherichia coli, purification, and characterization of the recombinant alginate lyase. World J. Microbiol. Biotechnol. 24: 89-96.

45. Miyake O, Ochiai A, Hashimoto W, Murata K. 2004. Origin and diversity of alginate lyases of families PL-5 and-7 in Sphingomonas sp. strain A1. J. Bacteriol. 186: 2891-2896.

46. Swift SM, Hudgens JW, Heselpoth RD, Bales PM, Nelson DC. 2014. Characterization of AlgMsp, an alginate lyase from Microbulbifer sp. 6532A. PLoS One 9: e112939.

47. Yoon HJ, Hashimoto W, Miyake O, Okamoto M, Mikami B, Murata K. 2000. Overexpression in Escherichia coli, purification, and characterization of Sphingomonas sp. A1 alginate lyases. Protein Expres Purif. 19: 84-90.

48. Hanahan D, Jessee J, Bloom F. 1991. Plasmid transformation of Escherichia coli and other bacteria. Method Enzymol. 204: 63-113.

49. Petersen TN, Brunak S, von Heijne G, Nielsen H 2011. SignalP 4.0: discriminating signal peptides from transmembrane regions. Nat. Methods 8: 785-786.

50. Rahman O, Cummings SP, Harrington DJ, Sutcliffe IC. 2008. Methods for the bioinformatic identification of bacterial lipoproteins encoded in the genomes of Gram-positive bacteria. World J. Microbiol. Biotechnol. 24: 2377-2382.

51. Fu C, Wehr DR, Edwards J, HaugeB. 2008. Rapid one-step recombinational cloning. Nucleic Acids Res. 36:e54.

52. Norholm MH. 2010. A mutant Pfu DNA polymerase designed for advanced uracil-excision DNA engineering. BMC Biotechnol. 10:1-7.

53. Busso D, Stierlé M, Thierry JC, Moras D. 2008. A comparison of inoculation methods to simplify recombinant protein expression screening in Escherichia coli. Biotechniques 44: 101-106.
54. Studier FW. 2005. Protein production by auto-induction in high-density shaking cultures. Protein Expres Purif. 41: 207-234.

55. Miller GL 1959. Use of dinitrosalicylic acid reagent for determination of reducing sugar. Anal. Chem. 31: 426-428.

56. Milner Y, Avigad G. 1967. A copper reagent for the determination of hexuronic acids and certain ketohexoses. Carbohydr. Res. 4: 359-361.

57. Lombard V, Ramulu HG, Drula E, Coutinho PM, Henrissat B. 2014. The carbohydrate-active enzymes database (CAZy) in 2013. Nucleic Acids Res. 42: D490-D495.

58. Dong S, Wei TD, Chen XL, Li CY, Wang P, Xie BB, et al. 2014. Molecular insight into the role of the N-terminal extension in the maturation, substrate recognition, and catalysis of a bacterial alginate lyase from polysaccharide lyase family 18. J. Biol. Chem. 289: 29558-29569.

59. Thomas F, Lundqvist LC, Jam M, Jeudy A, Barbeyron T, Sandström C, et al. 2013. Comparative characterization of two marine alginate lyases from Zobellia galactanivorans reveals distinct modes of action and exquisite adaptation to their natural substrate. J. Biol. Chem. 288: 23021-23037.

60. Johnson M, Zaretskaya I, Raytselis Y, Merezhuk Y, McGinnis S, Madden TL. 2008. NCBI BLAST: a better web interface. Nucleic Acids Res. 36 Suppl 2: W5-W9.

61. Jagtap SS, Hehemann JH, Polz MF, Lee JK, Zhao H.2014. Comparative biochemical characterization of three exolytic oligoalginate lyases from Vibrio splendidus reveals complementary substrate scope, temperature, and $\mathrm{pH}$ adaptations. Appl. Environ. Microb. 80: 4207-4214.

62. Ochiai A, Hashimoto W, Murata K. 2006. A biosystem for alginate metabolism in Agrobacterium tumefaciens strain C58: molecular identification of Atu3025 as an exotype family PL-15 alginate lyase. Res. Microbiol. 157: 642-649.

63. Nozach H, Fruchart-Gaillard C, Fenaille F, Beau F, Ramos OHP, Douzi B, et al. 2013. High throughput screening identifies disulfide isomerase DsbC as a very efficient partner for recombinant expression of small disulfide-rich proteins in E. coli. Microb. Cell Fact. 12: 1-16.

64. Vincentelli R, Cimino A, Geerlof A, Kubo A, Satou Y, Cambillau C, High-throughput protein expression screening and purification in Escherichia coli. Methods 55: 65-72.

65. Novy R, Drott D, Yaeger K, Mierendrof R. 2001. Overcoming the codon bias of $E$. coli for enhanced protein expression. Innovations 12: 1-3.

66. Pan SH, Malcolm BA. 2000. Reduced background expression and improved plasmid stability with pET vectors in BL21 (DE3). Biotechniques 29: 1234-1238.

67. Studier FW. 1991. Use of bacteriophage T7 lysozyme to improve an inducible T7 expression system. J. Mol. Biol. 219: 37-44.

68. Rosano G, Ceccarelli E. 2014. Recombinant protein expression in Escherichia coli: advances and challenges. Front Microbiol. 5: 172. 